\title{
Direct Effects of Leptin on Brown and White Adipose Tissue
}

\author{
Catherine A. Siegrist-Kaiser, ${ }^{\star}$ Véronique Pauli, ${ }^{*}$ Cristiana E. Juge-Aubry, ${ }^{\star}$ Olivier Boss, ${ }^{\ddagger}$ Agnès Pernin, ${ }^{\star}$ William W. Chin,, \\ Isabelle Cusin," Françoise Rohner-Jeanrenaud," Albert G. Burger, ${ }^{\star}$ Jürgen Zapf," and Christoph A. Meier ${ }^{\star \star \star \star \ddagger \ddagger}$ \\ *Unité de Thyrö̈de, Division d'Endocrinologie et Diabétologie, Hôpital Universitaire de Genève, ${ }^{\ddagger}$ Biochimie Médicale, Centre Médical \\ Universitaire, Université de Genève, CH-1211 Geneva 14, Switzerland; ${ }^{\S}$ Division of Genetics, Brigham and Women's Hospital, Boston, \\ Massachusetts 02115; "Laboratoires des Recherches Métaboliques, Faculté de Médecine, Université de Genève, CH-1211 Geneva 14, \\ Switzerland; "Division of Endocrinology and Diabetes, University Hospital Zürich, CH-8091 Zurich, Switzerland; **Clinique de \\ Médecine II, Département de Médecine, Hôpital Universitaire de Genève, CH-1211 Geneva 14, Switzerland; and ${ }^{\ddagger \ddagger}$ Endocrine Division, \\ Massachusetts General Hospital, Boston, Massachusetts 02114
}

\begin{abstract}
Leptin is thought to exert its actions on energy homeostasis through the long form of the leptin receptor (OB-Rb), which is present in the hypothalamus and in certain peripheral organs, including adipose tissue. In this study, we examined whether leptin has direct effects on the function of brown and white adipose tissue (BAT and WAT, respectively) at the metabolic and molecular levels. The chronic peripheral intravenous administration of leptin in vivo for $4 \mathrm{~d}$ resulted in a 1.6-fold increase in the in vivo glucose utilization index of BAT, whereas no significant change was found after intracerebroventricular administration compared with pair-fed control rats, compatible with a direct effect of leptin on BAT. The effect of leptin on WAT fat pads from lean Zucker $\mathrm{Fa}$ / $f a$ rats was assessed ex vivo, where a 9- and 16-fold increase in the rate of lipolysis was observed after $2 \mathrm{~h}$ of exposure to 0.1 and $10 \mathrm{nM}$ leptin, respectively. In contrast, no increase in lipolysis was observed in the fat pads from obese $\mathrm{fa} / \mathrm{fa}$ rats, which harbor an inactivating mutation in the OB-Rb. At the level of gene expression, leptin treatment for $24 \mathrm{~h}$ increased malic enzyme and lipoprotein lipase RNA 1.8 \pm 0.17 and 1.9 \pm 0.14 -fold, respectively, while aP2 mRNA levels were unaltered in primary cultures of brown adipocytes from lean $\mathrm{Fa} / \mathrm{fa}$ rats. Importantly, however, no significant effect of leptin was observed on these genes in brown adipocytes from obese $\mathrm{fa} / \mathrm{fa}$ animals. The presence of OB-Rb receptors in adipose tissue was substantiated by the detection of its transcripts by RT-PCR, and leptin treatment in vivo and in vitro activated the specific STATs implicated in the signaling pathway of the $\mathrm{OB}-\mathrm{Rb}$.

Taken together, our data strongly suggest that leptin has direct effects on BAT and WAT, resulting in the activation of the Jak/STAT pathway and the increased expression of certain target genes, which may partially account for the ob-
\end{abstract}

Address correspondence to Dr. Christoph A. Meier, Division of Genetics, Thorn 10, Department of Medicine, Brigham and Women's Hospital, 20 Shattuck Street, Boston, MA 02115. Phone: 617-7325857; FAX: 617-732-5123.

Received for publication 24 March 1997 and accepted in revised form 10 October 1997.

J. Clin. Invest.

(c) The American Society for Clinical Investigation, Inc. 0021-9738/97/12/2858/07 \$2.00

Volume 100, Number 11, December 1997, 2858-2864

http://www.jci.org served increase in glucose utilization and lipolysis in leptintreated adipose tissue. (J. Clin. Invest. 1997. 100:2858-2864.) Key words: leptin • adipocytes • lipolysis • Jak/STAT

\section{Introduction}

Adipocyte differentiation and metabolism are regulated by a variety of endocrine and paracrine factors, including certain cytokines, such as IL-6 and TNF- $\alpha$ (1-3). The $o b$ gene product (leptin) was initially cloned in $o b / o b$ mice and shown to be a 167-amino acid cytokine-like peptide, secreted by adipocytes in a regulated fashion $(4,5)$. Subsequent physiological studies revealed that leptin was able to inhibit food intake and enhance energy expenditure by acting at the hypothalamic level, providing a feedback signal reflecting the nutritional status of the periphery $(6-8)$. The gene encoding a leptin receptor $(\mathrm{OB}-\mathrm{R})^{1}$ was cloned from hypothalamic cDNA, and several differentially expressed splice variants were detected in various other tissues (9-12). While most of these variants are currently thought to be involved in leptin binding and transport, the intracellular domain of the long form of the OB-R (OB-Rb) is homologous to the IL-6/gp130 receptor family (13). Several studies performed in vivo and in vitro demonstrated the capability of the OB-Rb to activate the Janus kinase (Jak)/signal transducers and activators of transcription (STAT) pathway, resulting in the nuclear translocation of specific STATs, such as STAT 1, 3, 5, and $6(12-16)$. Although the OB-Rb is highly expressed in the hypothalamus and the lymphoid system, the presence of small amounts of its mRNA was also demonstrated in other organs, including pancreatic $\beta$ cells and brown and white adipose tissue (BAT and WAT, respectively) (12, 17, 18). Recently, direct functional effects of leptin on some of these nonhypothalamic target organs were described, such as on hematopoietic cells, the endocrine pancreas, pituitary, and ovary (17, 19-23). However, no data are currently available on potential direct paracrine or autocrine effects of leptin on adipose tissue, although several studies have provided some evidence compatible with such an hypothesis (24-28).

In this study, we examined the effect of leptin on brown and white adipocytes in vivo, ex vivo, and in primary cultures to demonstrate direct actions of leptin on metabolism and gene expression. In addition, we provide evidence that leptin administration in vivo and in vitro activates the Jak/STAT pathway in adipocytes, resulting in the nuclear translocation of STAT1.

1. Abbreviations used in this paper: BAT, brown adipose tissue; Jak, Janus kinase; OB-R, leptin receptor; PPAR, peroxisome proliferatoractivated receptor; RT-PCR, reverse transcription PCR; STAT, signal transducers and activators of transcription; UCP, uncoupling protein; WAT, white adipose tissue. 


\section{Methods}

Measurement of glucose utilization in BAT in vivo. Freely moving adult male rats were infused for $4 \mathrm{~d}$ with vehicle $(0.1 \mathrm{M}$ Tris- $\mathrm{HCl}, \mathrm{pH}$ 9.0) or leptin $(12 \mu \mathrm{g} / \mathrm{d})$ administered into the lateral cerebral ventricle. Another group of rats was given either vehicle (Ringer solution) or $1 \mathrm{mg} / \mathrm{d}$ of recombinant mouse leptin (Novartis, Basel, Switzerland) for $4 \mathrm{~d}$ into the femoral vein via a custom-made device including a swivel mounted on a counterbalanced arm, supporting the catheters and allowing the animals to move freely. To eliminate the confounding variable of leptin-induced hypophagia, all vehicle-infused rats were pair-fed to the amount of food consumed by leptin-infused animals. At the end of the treatment period, the animals were anesthetized with $60 \mathrm{mg} / \mathrm{kg}$ sodium pentobarbital intraperitoneally and prepared for euglycemic-hyperinsulinemic clamps associated with the labeled 2-deoxyglucose technique to measure the insulin-stimulated glucose utilization index in BAT in vivo. This technique was described previously and validated (29-31).

Measurement of lipolysis in WAT fat pads ex vivo. Epididymal fat pads were removed and pooled from Sprague-Dawley (140-160 g) or lean $(F a / f a, 170-190 \mathrm{~g})$ or obese $(f a / f a, 205-230 \mathrm{~g})$ Zucker rats, and the amount of glycerol released into the medium was determined as described (32). Briefly, after a preincubation period of $1 \mathrm{~h}$, the pooled fat pads were incubated at $37^{\circ} \mathrm{C}$ for different time intervals in the presence of Krebs-Ringer-Hepes buffer containing dialyzed human serum albumin $(30 \mathrm{mg} / \mathrm{ml}), 2 \mathrm{mg} / \mathrm{ml}$ glucose, as well as epinephrine $(0.5-5,000 \mathrm{nM})$ or leptin $(0.1-1,000 \mathrm{nM})$, as appropriate. After the incubation period, glycerol release into the medium was determined and the results were expressed as micromoles of glycerol released per $100 \mathrm{mg}$ of adipose tissue per hour. The fat pads from the leptin-resistant obese $f a / f a$ rats served as negative controls for these experiments.

Primary culture of BAT and WAT. 3-wk-old male lean Zucker $\mathrm{Fa} / \mathrm{fa}$ rats were killed and interscapular BAT as well as inguinal WAT were immediately removed. For both tissues, precursor cells were isolated as reported elsewhere and suspended in a (1:1 vol/vol) mixture of Dulbecco's modified Eagle's medium and Ham's F-12, supplemented with $16 \mu \mathrm{M}$ biotin, $18 \mu \mathrm{M}$ pantothenic acid, $5 \mathrm{mM}$ glutamine, $16 \mathrm{mM}$ glucose, $15 \mathrm{mM}$ Hepes, penicillin $50 \mathrm{IU} / \mathrm{ml}$, streptomycin 50 $\mu \mathrm{g} / \mathrm{ml}, 100 \mu \mathrm{M}$ ascorbate, and $10 \%$ fetal calf serum (complete medium) (33). The medium was changed on day 1 and replaced with a differentiation medium containing $510 \mathrm{nM}$ insulin, $100 \mathrm{nM}$ dexamethasone, $0.2 \mathrm{nM}$ L-triiodothyronine, and $10 \mu \mathrm{g} / \mathrm{ml}$ transferrin in complete medium (34). The medium was changed every $2 \mathrm{~d}$ until the cells were fully differentiated after $14 \mathrm{~d}$, as ascertained by the presence of lipid accumulation and the expression of uncoupling protein-1 (UCP-1) mRNA. The brown adipocytes from the leptinresistant obese $f a / f a$ rats served as negative controls for these experiments.

Analysis of gene expression in brown adipocytes. Fully differentiated brown adipocytes were treated for $24 \mathrm{~h}$ with $1 \mu \mathrm{M}$ BRL49653 (kind gift of Dr. W. Wahli, Lausanne, Switzerland), $625 \mathrm{nM}$ leptin, or a combination of both. Total RNA was isolated by guanidinium isothiocyanate extraction (35). Cells were lysed in a $4 \mathrm{M}$ guanidinium thiocyanate solution containing $5 \mathrm{mM}$ sodium citrate, $\mathrm{pH} 7.0,0.5 \%$ sarcosyl, and $0.1 \mathrm{M} \beta$-mercaptoethanol and ultracentrifuged overnight through a CsCl step gradient. RNA ( $15 \mu \mathrm{g} / \mathrm{sample})$ was denatured and subjected to electrophoresis on a $1 \%$ agarose-formaldehyde gel before blotting and ultraviolet cross-linking onto a nylon membrane (NYTRAN $13 \mathrm{~N}$; Schleicher \& Schuell, Dassel, Germany).

The probes for malic enzyme (EcoRI insert from pME6, kindly provided by Dr. V. Nikodem, Bethesda, MD), lipoprotein lipase (EcoRI insert from pGEM2, kindly provided by Dr. M. Schotz, Los Angeles, CA), and aP2 (PstI insert from pAL422, kindly provided by Dr. D. Lane, Baltimore, MD) were labeled with $50 \mu \mathrm{Ci}\left[\alpha{ }^{-32} \mathrm{P}\right] \mathrm{dCTP}$ (Rediprime random primer labeling kit; Amersham, Buchs, Switzerland) to a specific activity of at least $2 \times 10^{9} \mathrm{cpm} / \mu \mathrm{g}(36,37)$. Hybridization was carried out for $2 \mathrm{~h}$ with $2 \mathrm{ng} / \mathrm{ml}$ of labeled probe, using the RapidHyb buffer (Amersham). Membranes were washed, with the last step being $0.1 \times \mathrm{SSC}, 0.1 \%$ SDS at $65^{\circ} \mathrm{C}$ for $15 \mathrm{~min}$. The autoradiograms were quantified by laser scanning densitometry (Molecular Dynamics, Sunnyvale, CA). The results were corrected for $18 \mathrm{~S}$ and $28 \mathrm{~S}$ ribosomal RNA on the gel as quantitated by scanning densitometry.

Reverse transcription PCR (RT-PCR) assay for the detection of $O B-R b$. RNA was prepared from the hypothalamus, WAT, and BAT, as well as cultured brown and white adipocytes as described above. $5 \mu \mathrm{g}$ of total RNA was used for reverse transcription with Moloney murine leukemia virus reverse transcriptase $(2 \times 40 \mathrm{~min}$, $37^{\circ} \mathrm{C}$ ), primed by oligo-dT 18 . Primers for PCR amplification were synthesized according to the published sequence for the long form of the rat OB-R (OB-Rb, GenBank accession No. D85558), and the cDNA was amplified using the sense primer OB1F (nucleotides 2541-2564: 5'-TATGTCATTGTACCGATAATTATT-3') and the reverse primer OB1R (nucleotides 2895-2913: 5'-CAGAGAAGTTAGCACTGTT-3'). All PCR reactions were carried out in standard buffer $[10 \mathrm{mM}$ $\mathrm{KCl}, 20 \mathrm{mM}$ Tris- $\mathrm{HCl}, \mathrm{pH} 8,0.1 \%$ Triton $\mathrm{X}-100,6 \mathrm{mM}\left(\mathrm{NH}_{4}\right)_{2} \mathrm{SO}_{4}$, $0.2 \mathrm{mM}$ dNTP, $2 \mathrm{mM} \mathrm{MgCl}_{2}, 0.5 \mu \mathrm{M}$ of each primer, $2.5 \mathrm{U} / 100 \mu \mathrm{l}$ of native $P f u$ (Stratagene, Basel, Switzerland)], for $>40$ cycles with the following temperatures: denaturation $30 \mathrm{~s}$ at $92^{\circ} \mathrm{C}$, annealing $30 \mathrm{~s}$ at $50^{\circ} \mathrm{C}$, and elongation for $90 \mathrm{~s}$ at $72^{\circ} \mathrm{C}$. The PCR products were analyzed on a $2 \%$ agarose gel and stained with ethidium bromide. The PCR products obtained from WAT and BAT and culture were sequenced by direct sequencing using standard protocols for the ABI373A automated sequencer with primers OB1F and OB1R.

Preparation of nuclear extracts. Lean male $F a / f a$ Zucker rats were injected intravenously with either vehicle or $500 \mu \mathrm{g}$ of leptin in Tris $0.1 \mathrm{M}, \mathrm{pH}$ 8.1. After 60 and $90 \mathrm{~min}$, the animals were killed and BAT was removed. Nuclear extracts were prepared as described elsewhere (15). Briefly, tissues were homogenized in $10 \mathrm{mM} \mathrm{KCl}, 1.5 \mathrm{mM}$ $\mathrm{MgCl}_{2}, 10 \mathrm{mM}$ Hepes, pH 7.9, $1 \mathrm{mM}$ DTT, $1 \mathrm{mM} \mathrm{Na} \mathrm{VO}_{4}, 10 \mu \mathrm{g} / \mathrm{ml}$ leupeptin, $0.3 \mathrm{TIU} / \mathrm{ml}$ aprotinin, $1 \mu \mathrm{M}$ pepstatin $\mathrm{A}$, and $1 \mathrm{mM}$ PMSF. The homogenate was centrifuged at 2,000 $\mathrm{g}$ for $10 \mathrm{~min}$ and the pellet was washed with the same buffer. The washed pellet was resuspended in a buffer containing $420 \mathrm{mM} \mathrm{NaCl}, 10 \mathrm{mM} \mathrm{KCl}, 20 \mathrm{mM}$ Hepes, $\mathrm{pH}$ 7.9, $20 \%$ glycerol, $1 \mathrm{mM}$ DTT, $1 \mathrm{mM} \mathrm{Na}_{3} \mathrm{VO}_{4}$, and the protease inhibitors specified above. Nuclei were extracted for $30 \mathrm{~min}$ at $4^{\circ} \mathrm{C}$ on a shaking rotor and centrifuged for $10 \mathrm{~min}$ at $16,000 \mathrm{~g}$. Supernatants were diluted in a buffer containing $10 \mathrm{mM} \mathrm{KCl}, 20 \mathrm{mM}$ Hepes, $\mathrm{pH} 7.9,20 \%$ glycerol, $1 \mathrm{mM}$ DTT, $1 \mathrm{mM} \mathrm{Na}_{3} \mathrm{VO}_{4}$, and the protease inhibitors specified above. After additional centrifugation, the supernatants were concentrated on a Microcon-50 ultrafiltration column (Amicon, Wallisellen, Switzerland).

Nuclear extracts from primary brown or white adipocyte cultures were prepared as follows (38). Cells were cultured in 6-cm petri dishes as described above. The cells were placed in serum-free medium for $4 \mathrm{~h}$ before stimulation with $0.2 \mu \mathrm{M}$ leptin for 15 or $30 \mathrm{~min}$ as indicated. Cells were washed with $2 \mathrm{ml}$ of cold PBS and scraped off the dish in $1 \mathrm{ml}$ of PBS. Two plates were pooled for nuclear protein extraction. Cells were pelleted by centrifugation at $5,200 \mathrm{~g}$ for $15 \mathrm{~s}$. The pellet was resuspended in $400 \mu \mathrm{l}$ of hypotonic buffer $(10 \mathrm{mM}$ Hepes, pH 7.9, $10 \mathrm{mM} \mathrm{KCl,} 0.1 \mathrm{mM}$ EDTA, $0.1 \mathrm{mM}$ EGTA, $1 \mathrm{mM}$ DTT, $1 \mathrm{mM}$ PMSF, and $0.5 \mathrm{mM} \mathrm{Na} \mathrm{VO}_{4}$ ) by gentle pipetting. The cells were left to swell for $15 \mathrm{~min}$ on ice, after which $25 \mu \mathrm{l}$ of $1 \% \mathrm{NP}$ 40 was added and the tubes were vigorously vortexed. After spinning at $15,800 \mathrm{~g}$ for $30 \mathrm{~s}$, the pellet was resuspended by mild vortexing in $50 \mu \mathrm{l}$ of cold hypertonic buffer ( $20 \mathrm{mM}$ Hepes, pH 7.9, $0.4 \mathrm{M} \mathrm{NaCl}, 1 \mathrm{mM}$ EDTA, $1 \mathrm{mM}$ EGTA, 20\% glycerol, $1 \mathrm{mM}$ DTT, $1 \mathrm{mM}$ PMSF, and $\left.0.5 \mathrm{mM} \mathrm{Na}_{3} \mathrm{VO}_{4}\right)$. After $15 \mathrm{~min}$ of incubation, the tubes were centrifuged for $5 \mathrm{~min}$ at $15,800 \mathrm{~g}$ at $4^{\circ} \mathrm{C}$. Supernatants were aliquoted and stored at $-70^{\circ} \mathrm{C}$. The protein concentration in the nuclear extracts was determined by the Bradford assay (BioRad, Glattbrugg, Switzerland).

Activation of STATs in vivo and in vitro (EMSA). A doublestranded oligonucleotide (Microsynth, Balgach, Switzerland) containing a binding site (M67-SIE) for STAT1, 3, and 4, was labeled by fill-in with Klenow DNA polymerase in the presence of $\left[\alpha-{ }^{32} \mathrm{P}\right] \mathrm{dATP}$ (39). $3 \mu \mathrm{g}$ of nuclear extracts from the primary cell cultures, or $5 \mu \mathrm{g}$ of 
nuclear extracts from BAT, was incubated with $25,000 \mathrm{cpm}$ of the labeled M67-SIE, and $2 \mu \mathrm{g}$ of poly [d(I-C)] in EMSA binding buffer $(50 \mathrm{mM} \mathrm{KCl}, 20 \mathrm{mM}$ Hepes, $20 \%$ glycerol, $0.05 \% \mathrm{NP}-40,10 \mathrm{mM}$ $\beta$-mercaptoethanol, $\mathrm{pH} 7.5)$ with a final volume of $25 \mu$ l. Incubation was performed at room temperature for $20 \mathrm{~min}$ and the samples were analyzed on a $5 \%$ polyacrylamide gel in $0.5 \times$ TBE $(44.5 \mathrm{mM}$ Tris, $44.5 \mathrm{mM}$ boric acid, $1 \mathrm{mM}$ EDTA, pH 8) for $75 \mathrm{~min}$ at $300 \mathrm{~V}$. Gels were dried and then autoradiographed.

For the supershift assay, either 0.3 or $0.75 \mu \mathrm{g}$ of a mouse monoclonal IgG1 anti-STAT1 antibody (Santa Cruz Biotechnology, Basel, Switzerland) or of an anti-STAT3 antibody, respectively, was added to the EMSA incubation mixture for $15 \mathrm{~min}$ before the addition of the labeled oligonucleotide.

Statistical analysis. Results are expressed as the mean \pm SEM and the unpaired Student's $t$ test was used to assess statistical significance. $P>0.05$ was considered not significant (NS).

Others. All experimental animal protocols were approved by the Review Board for Animal Experimentation of the Canton of Geneva, Switzerland.

\section{Results}

Leptin enhances glucose utilization of BAT in vivo. To assess direct peripheral effects of leptin on BAT, male rats were given leptin either intracerebroventricularly or intravenously for $4 \mathrm{~d}$, and euglycemic-hyperinsulinemic clamps were performed to determine the insulin-stimulated glucose utilization index. As shown in Fig. $1 A$, the glucose utilization index in BAT remained unchanged in rats treated with leptin intracerebroventricularly, as compared with pair-fed controls (195 \pm 23 vs. $174 \pm 11 \mathrm{ng} / \mathrm{min} / \mathrm{mg}$ tissue, NS). In contrast, when leptin was administered intravenously, the insulin-stimulated glucose utilization index increased 1.6-fold to $320 \pm 45 \mathrm{ng} / \mathrm{min} / \mathrm{mg}$ tissue, compared with $196 \pm 14 \mathrm{ng} / \mathrm{min} / \mathrm{mg}$ tissue in pair-fed controls $(P<0.05)$. Hence, the peripheral, but not central, administration of leptin enhances glucose utilization in BAT compared with pair-fed control rats, compatible with a direct peripheral effect of leptin on this tissue.
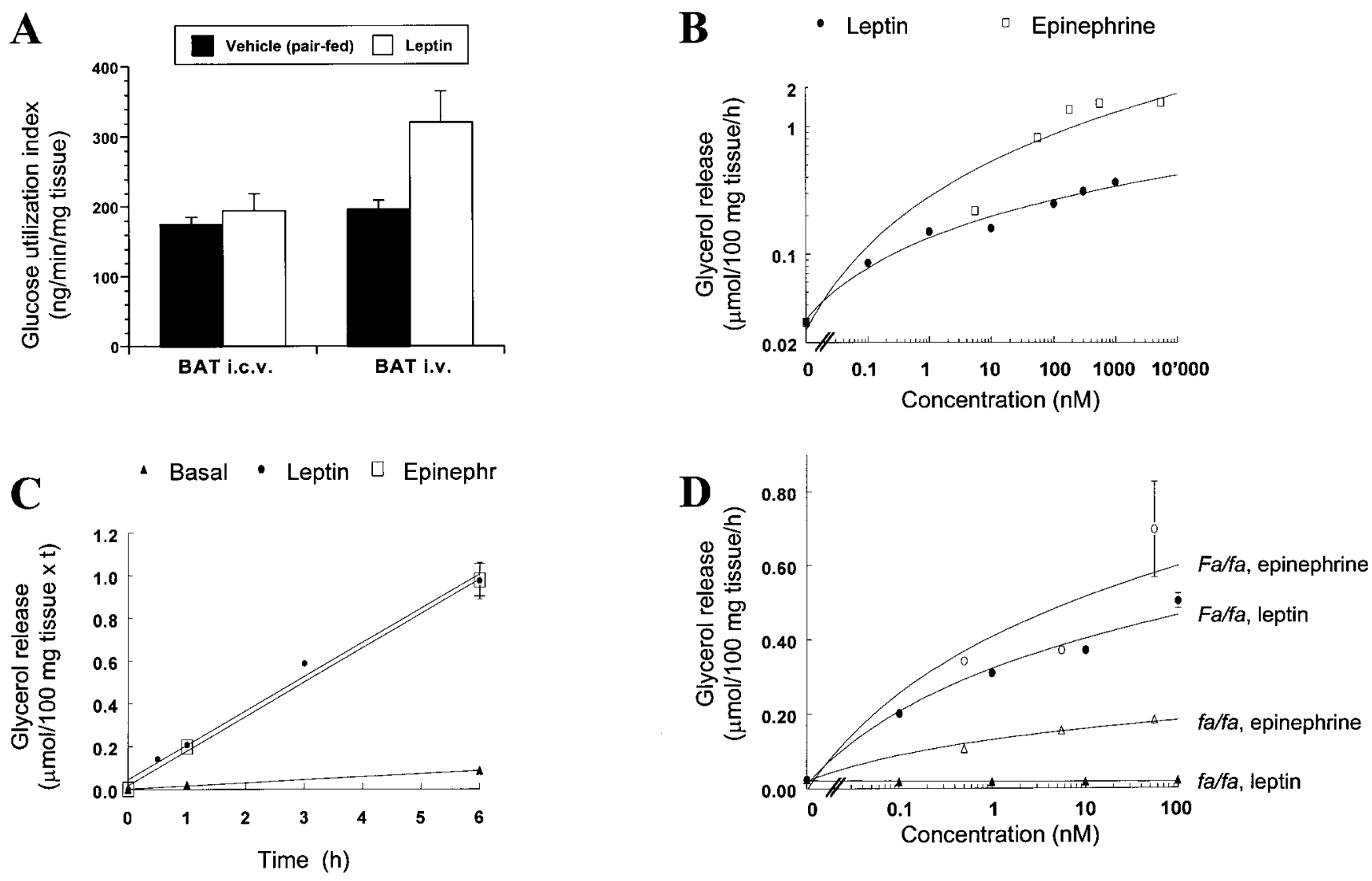

Figure 1. Effects of leptin on adipocyte metabolism. $(A)$ Leptin enhances the insulin-stimulated glucose utilization index in vivo compared with pair-fed control rats. Rats were injected for $4 \mathrm{~d}$ with vehicle, or leptin intravenously $(1 \mathrm{mg} / \mathrm{d})$ or intracerebroventricularly (i.c.v.) $(12 \mu \mathrm{g} / \mathrm{d})$, while the control animals were pair-fed to the controls during the entire experiment. At the end of the treatment period, the rats were used for euglycemic-hyperinsulinemic clamps, where the uptake of 2-deoxyglucose into brown adipose was measured ( $n=5-6$ per group). ( $B)$ Concentrationdependent increase in the basal lipolytic rate of ex vivo white fat pads from Sprague-Dawley rats in response to leptin and epinephrine. White fat pads from four animals were pooled and incubated as described in the text. After $1 \mathrm{~h}$ of incubation in the presence of either vehicle, leptin or epinephrine, the amount of glycerol released into the medium was measured (32) $(n=2-4$; where no error bars are visible the SEM is $<10 \%)$. $(C)$ Time-dependent increase in the lipolytic rate of ex vivo white fat pads from four Sprague-Dawley rats in response to vehicle (basal), leptin (10 $\mathrm{nM})$, or epinephrine $(5 \mathrm{nM})$. The experimental methods are identical to those in $B(n=2$; where no error bars are visible the SEM is $<10 \%)$. $(D)$ Leptin stimulates lipolysis in ex vivo white fat pads from lean Zucker $F a / f a$ rats, but not in WAT from obese $f a / f a$ animals, while the white fat pads from both animals respond to epinephrine. The experimental methods are identical to those in $B(n=2$; where no error bars are visible the SEM is $<10 \%$ ). 
Leptin increases lipolysis in WAT fat pads ex vivo. The effect of leptin on the basal lipolytic rate of epididymal fat pads was assessed ex vivo. As shown in Fig. 1, $B$ and $C$, leptin increases glycerol release in a dose- and time-dependent manner in fat pads from Sprague-Dawley rats, where leptin is a strong stimulator of lipolysis. On a molar basis, epinephrine stimulated lipolysis about fourfold more potently than leptin. To ascertain that this effect is indeed mediated by leptin and the OB-Rb, a similar experiment was performed in lean $(F a / f a)$ and obese $(f a / f a)$ Zucker rats. As shown in Fig. $1 D$, epinephrine was able to enhance the glycerol release in the fat pads from $F a / f a$ and $f a / f a$ animals, as expected, whereas only the leptin-sensitive $F a / f a$ animals responded to leptin in a dosedependent manner.

Effects of leptin treatment on gene expression in brown adipocytes. Primary cultures of in vitro differentiated brown adipocytes from genetically lean $F a / f a$ or obese $f a / f a$ rats were treated for $24 \mathrm{~h}$ with either $1 \mu \mathrm{M}$ of the thiazolidinedione BRL49653, $625 \mathrm{nM}$ of leptin, or both. Analysis of the extracted total RNA by Northern blotting after treatment with BRL49653 revealed as expected an about twofold increase in the mRNA for malic enzyme, lipoprotein lipase, and the fatty acid-binding protein, $\mathrm{aP} 2$, in brown adipocytes derived from lean rats (Fig. 2) (40-42). Interestingly, treatment with leptin resulted in a similar increase in malic enzyme and lipoprotein lipase mRNA (1.8 \pm 0.17 and $1.9 \pm 0.14$-fold, respectively; $P<0.01$ compared with control), while the expression of the $a P 2$ gene remained unaltered. The combined treatment with leptin and BRL49653 resulted in a partially additive effect on malic enzyme expression (3.1 \pm 0.22 -fold, $P<0.05$ compared with BRL alone). In contrast, the brown adipocyte cultures from obese Zucker $\mathrm{fal}$ $f a$ rats harboring a partially inactivating mutation in the OB$\mathrm{Rb}$ did not respond to leptin (0.73-fold stimulation), although the thiazolidinedione BRL49653 induced gene expression as expected (2.2-fold) (43-45).

Adipose tissue expresses $O B-R b$. The presence of small amounts of OB-Rb in adipose tissue has been reported previously (12). Using total RNA extracted from rat hypothalamus, BAT, and WAT, as well as from primary brown and white adipocyte cultures, we performed RT-PCR to demonstrate the presence of OB-Rb transcripts. The amplified products derived from native and cultured adipocytes were sequenced, confirming the presence of the correct PCR product (data not shown). With this assay, OB-Rb mRNA could be detected in tissue samples as well as cultures derived from BAT (Fig. 3). Lean $F a / f a$ rats as well as obese $f a / f a$ animals expressed OB-Rb as expected, since the $f a$ missense mutation alters intracellular trafficking, rather than expression of the OB-R (43). Similar results were obtained for native and cultured WAT (data not shown).

Leptin activates STATs in brown and white adipocytes. To determine whether leptin is capable of activating the Jak/ STAT pathway in adipocytes, as previously reported for the hypothalamus, we examined whether leptin would induce nuclear STAT translocation in vivo and in cultured primary adipocytes (15). Nuclear extracts were prepared from BAT 60 and 90 min after the intravenous injection of $F a / f a$ rats with $500 \mu \mathrm{g}$ of leptin. The extracts were assayed for the presence of specific STATs by means of an EMSA. Leptin strongly induced the translocation of STAT1, as demonstrated by binding to the M67-SIE DNA element and supershifting with an antiSTAT1, but not anti-STAT3, antibody (Fig. $4 A$ ). In contrast,
A

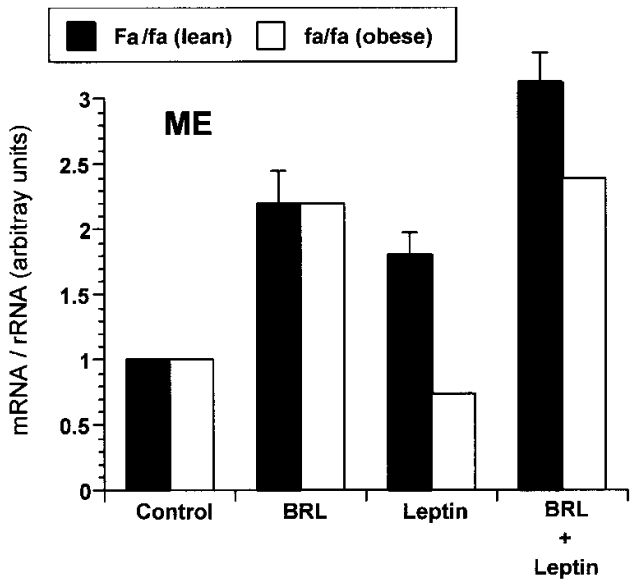

B

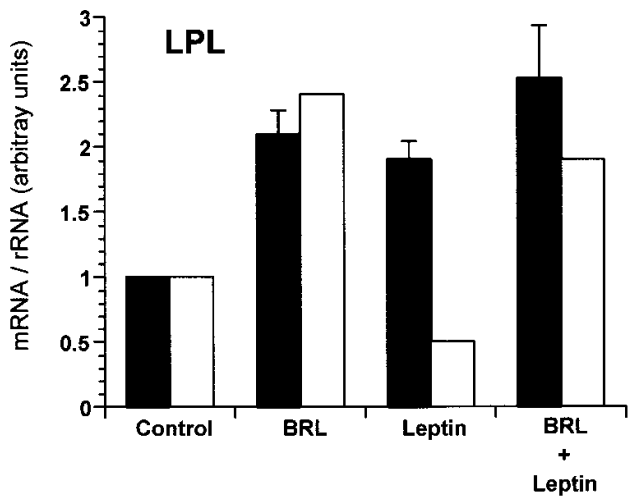

C

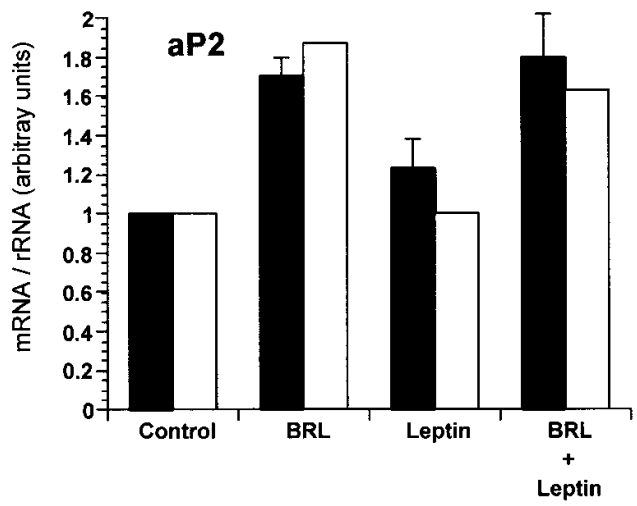

Figure 2. Effect of leptin on gene expression in primary cultures of brown adipocytes. Northern blot of total RNA isolated from brown adipocytes after treatment for $24 \mathrm{~h}$ with vehicle (Control), $1 \mu \mathrm{M}$ BRL49653 (BRL), and/or $625 \mathrm{nM}$ leptin. Equal amounts of RNA $(15 \mu \mathrm{g})$ were loaded on each lane and, after transfer, the membrane was hybridized with the probe for malic enzyme. The experiments were repeated at least three times in adipocytes derived from $\mathrm{Fa} / \mathrm{fa}$ rats. The results were normalized to the $18 \mathrm{~S}$ and $28 \mathrm{~S}$ rRNA bands and expressed as the mean \pm SEM. ( $A$ ) Quantitation of three different experiments examining the effects of BRL and/or leptin on malic enzyme $(M E)$ mRNA in brown adipocytes from lean $F a / f a$ rats and of one parallel experiment in obese $f a / f a$ animals (for the $F a / f a$ animals: control vs. leptin $P<0.01$; BRL vs. BRL + leptin $P<0.05)$. (B) Quantitation of three different experiments examining the effects of BRL and/or leptin on lipoprotein lipase ( $L P L)$ mRNA in brown adipocytes from lean $\mathrm{Fa} / \mathrm{fa}$ rats and of one parallel experiment in obese $f a / f a$ animals (for the $F a / f a$ animals: control vs. leptin $P<0.01$; BRL vs. BRL + leptin, NS). (C) Quantitation of three different experiments examining the effects of BRL and/or leptin on aP2 RNA in brown adipocytes from lean $\mathrm{Fa} / \mathrm{fa}$ rats and of one parallel experiment in obese $f a / f a$ animals (for the $F a / f a$ animals: control vs. leptin, NS; BRL vs. BRL + leptin, NS). 


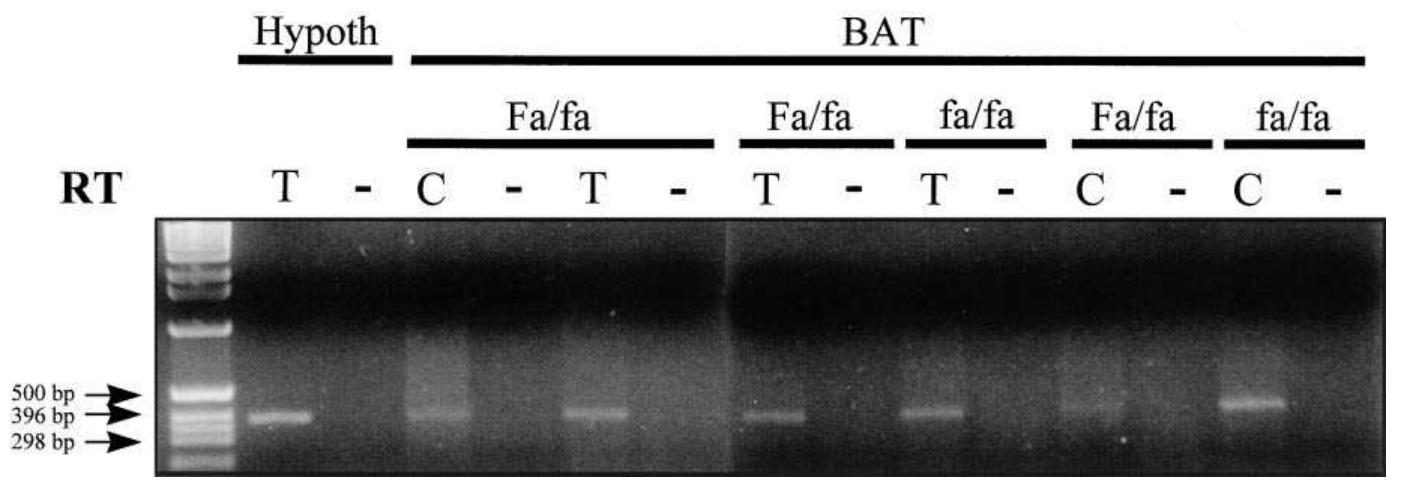

Figure 3. Detection of OB-Rb by RT-PCR in hypothalamus (Hypoth) as well as tissue $(T)$ and primary cultures $(C)$ from BAT from lean $F a / f a$ and obese $f a / f a$ rats. The PCR products were run on an ethidium bromidestained $2 \%$ agarose gel. The products were of the expected size ( $371 \mathrm{bp}$ ) and the specificity of the amplification was further assessed by direct sequencing of the PCR products derived from adipose tissue and culture. No band was present in the control reactions (-) where the reverse transcriptase was omitted.

A

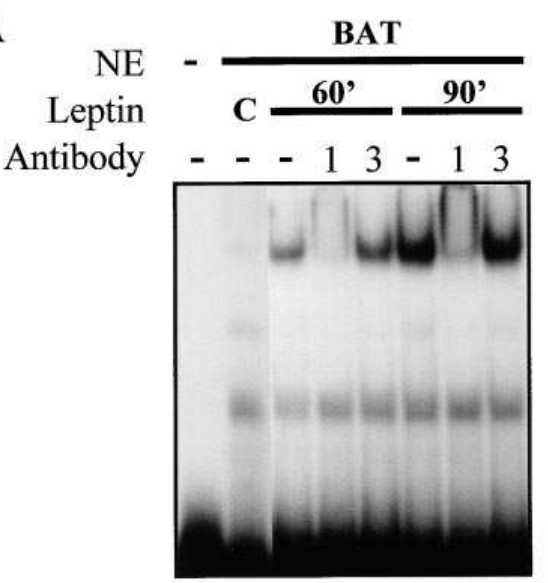

B

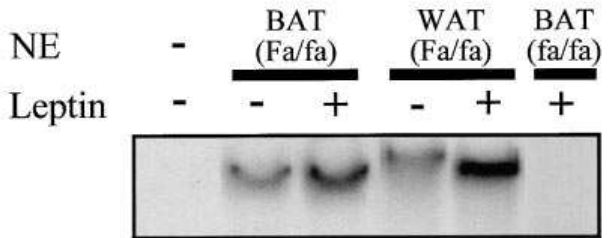

C

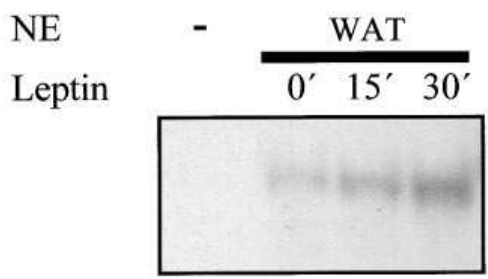

Figure 4. Effect of leptin on the nuclear translocation of STATs in nuclear extracts $(N E)$ prepared from BAT $(A)$ or primary cultures of BAT and WAT ( $B$ and $C$ ) from Zucker rats. The extracts were analyzed by EMSA on the M67-SIF probe, which binds STAT1 and 3. (A) Leptin treatment in vivo increases STAT activity in BAT after 60 and 90 min compared with control $(C)$. Antibodies against STAT1, but not against STAT3, eliminate the band shift. (B) Leptin treatment for 15 min increases STAT activity in NE from cultured BAT and WAT derived from lean $\mathrm{Fa} / \mathrm{fa}$ rats when assessed on the M67-SIF element. However, leptin fails to induce STAT activation in cultured BAT from obese $f a / f a$ animals (right-most lane). (C) Time course of the effect of leptin on STAT activity in cultured WAT. and in parallel with the data on glucose utilization (Fig. $1 A$ ), no peripheral activation of STATs was observed after the administration of $12 \mu \mathrm{g}$ of leptin i.c.v. (data not shown).

To determine whether these effects of leptin were direct, primary brown and white adipocyte cultures were treated with leptin and the nuclear extracts assayed for STAT activity. Leptin-inducible binding of STATs in the nuclear extracts from brown and white adipocytes increased 1.8- and 2.7-fold, respectively, after $15 \mathrm{~min}$ on the M67-SIF element, which binds STAT1 and 3 (Fig. $4 \mathrm{~B}$ ). The shift in mobility of the band observed after treatment of white adipocytes with leptin suggests the possible transition from hetero- to homodimeric complexes or vice versa. However, no activation of STATs was observed in primary cultures of BAT from obese $f a / f a$ rats, compatible with the genetic leptin resistance of these animals (Fig. $4 \mathrm{~B}$, right-most lane). Interestingly, even basal STAT activity was absent in the $f a / f a$ adipocytes, suggesting either that the basal signal observed in $\mathrm{Fa} / \mathrm{fa}$ cells is due to the paracrine effects of leptin secreted in culture, or, alternatively, due to a general desensitization of STAT signaling in $f a / f a$ adipocytes. Time course experiments performed in WAT demonstrated a rapid increase in STAT translocation at $15 \mathrm{~min}$ (1.7-fold), which increased further after 30 min (3.1-fold; Fig. 4 C).

\section{Discussion}

In this paper, we demonstrate that leptin has direct effects on BAT and WAT at a metabolic and molecular level. This conclusion is supported by several independent lines of evidence: (a) peripheral, but not central, administration of leptin increases the insulin-stimulated utilization of glucose in BAT when compared with pair-fed control rats; $(b)$ leptin at concentrations as low as $0.1 \mathrm{nM}$ stimulates basal lipolysis in white fat pads ex vivo in a time- and dose-dependent manner, and this effect is absent in fat pads from obese $f a / f a$ rats which are known to be deficient in functional OB-R; $(c)$ leptin induces the expression of malic enzyme and lipoprotein lipase in primary cultures of brown adipocytes; $(d)$ BAT, WAT, and primary adipocyte cultures all express OB-Rb mRNA; and (e) treatment of brown and white adipocytes with leptin in vivo or in vitro induces the nuclear translocation of STATs, compatible with the currently known mechanism of action of leptin through the OB-R. Taken together, our results suggest that 
leptin has direct auto- or paracrine effects on adipocytes, which possibly contribute to the weight- and fat-reducing activity of leptin.

While the hypothalamus was the first target organ described for leptin, recent evidence at the level of mRNA and cellular function suggests that peripheral organs also express $\mathrm{OB}-\mathrm{Rb}$ and are responsive to leptin $(12,17,22)$. Specifically, several recent reports demonstrated an inhibitory effect of leptin on the release of insulin from pancreatic $\beta$ cells, and another paper reported decreased synergism of insulin-like growth factor I on the follicle-stimulating hormone-induced estradiol synthesis when leptin was present $(17,19,20)$. In addition, leptin was shown to increase the pituitary secretion of luteinizing hormone, independent of any confounding hypothalamic effects (22). We now show that leptin increases glucose utilization in BAT in vivo and the rate of lipolysis in white fat pads ex vivo. This latter result is compatible with the recent observations of Shimabukuro et al. that leptin treatment in vivo dramatically reduces tissue triglyceride stores compared with pair-fed controls, already suggesting a role for leptin beyond its appetite-reducing properties $(25,26)$. In addition, the same group has demonstrated increased lipolysis and the increased expression of lipolytic enzymes in primary cultures of pancreatic islets, analogous to our findings in white fat pads (28). However, other groups have failed to detect a significant effect of leptin on basal lipolysis in cultured adipocytes in vitro (27). Our positive results in this study are likely due to the use of intact fat pads ex vivo, since the model of isolated adipocytes used in the negative reports was shown previously to be less responsive to other lipolytic stimuli, such as epinephrine (Zapf, J., unpublished data). The observation that already $0.1 \mathrm{nM}$ of leptin is able to stimulate basal lipolysis and that fat pads from Zucker $f a / f a$ rats, which are known to harbor a partially inactivating mutation in the $O B-R b$ gene, are unresponsive to leptin suggests that this effect is specific and of potential of physiological relevance. However, the possibility cannot be excluded that the adipocytes from $f a / f a$ animals have acquired postreceptor defects related to their obese and insulin-resistant state, contributing to their unresponsiveness to the lipolytic action of leptin. Nevertheless, the observation that leptin fails to activate STATs in brown adipocytes derived from the leptin-resistant $f a / f a$ animals is compatible with the concept that the observed direct effects of leptin might be mediated through the OB-R.

Leptin also enhances the mRNA expression of malic enzyme and lipoprotein lipase, but not of the fatty acid-binding protein aP2, in brown adipocytes from lean $\mathrm{Fa} / \mathrm{fa}$ rats, but not in brown adipocytes derived from obese Zucker $f a / f a$ rats. The only gene shown previously to be regulated directly by leptin in a preadipocyte cell line is the acetyl-CoA carboxylase gene, which is suppressed in the presence of leptin (24). Since the malic enzyme and lipoprotein lipase genes are both regulated by the peroxisome proliferator-activated receptors (PPARs), it is conceivable that leptin activates this nuclear receptor pathway. However, the fact that leptin does not significantly increase aP2 mRNA, which represents another PPAR-regulated gene, suggests that any putative functional interaction between the OB-R and PPAR signaling pathways is more complex. Since leptin not only decreases food intake, but also increases energy expenditure, we examined its effect on the expression of UCP-1 in brown adipocyte cultures. However, we were unable to detect any chances in the levels of UCP-1
mRNA after leptin treatment, and hence it remains to be seen whether the direct effects of leptin on BAT are implicated in regulating thermogenesis (data not shown).

The levels of OB-Rb in all target organs other than the hypothalamus and the hematopoietic system are very low, requiring RT-PCR or RNase protection assays for the detection of transcripts. In this study, we were able to detect $\mathrm{OB}-\mathrm{Rb}$ mRNA in BAT, WAT, and primary adipocyte cultures, which is compatible with previous reports demonstrating the presence of OB-Rb mRNA in adipose tissue by RNase protection $(12,18)$. However, other than the hypothalamus, no target tissue for leptin was hitherto shown to respond by nuclear STAT translocation (15). The present experiments demonstrate that the peripheral, but not central, administration of leptin in vivo activates STAT1 in BAT. Experiments with primary cultures of brown and white adipocytes suggest that this effect of leptin on adipocytes is indeed direct and does not involve the hypothalamus. However, the exact nature of the STATs required for transducing the leptin signal is still controversial and may depend on the cellular context and the concomitant presence of other stimuli in vivo. For example, a previous in vivo study implicated only STAT3 in hypothalamic leptin signaling, whereas experiments involving transfected cells have provided evidence for the activation of either STAT3, 5, 6, STAT1, 3, 5, or only STAT1 and 3, depending on the cellular model (12-15).

In summary, we have shown that physiological levels of leptin have direct and specific effect on the metabolism and gene expression of brown and white adipocytes. These observations suggest that leptin may exert its weight-reducing action not only through an endocrine, hypothalamic mode of action, but also through an auto- or paracrine pathway.

\section{Acknowledgments}

We are grateful to Dr. D. Lane for providing the aP2 probe, to Dr. M. Schotz for the lipoprotein lipase probe, and Dr. V. Nikodem for the malic enzyme cDNA. Leptin was kindly provided by Novartis. The expert technical assistance of Mrs. Mireille de Meyer and Mrs. Marjana Paponja is gratefully acknowledged.

C.A. Meier is supported by a Fellowship from the Howard Hughes Medical Institute. The work was supported by the Swiss National Science Foundation (grants 32-37536.93 to A.G. Burger and C.A. Meier, and 32-046808.96 to J. Zapf) and also in part through a grant-in-aid from Boehringer-Ingelheim International Inc. (to C.A. Meier).

\section{References}

1. Spiegelman, B.M., and J.S. Flier. 1996. Adipogenesis and obesity: rounding out the big picture. Cell. 87:377-389.

2. Stouthard, J.M.L., R.P.J.O. Elferink, and H.P. Sauerwein. 1996. Interleukin-6 enhances glucose transport in 3T3-L1 adipocytes. Biochem. Biophys. Res. Commun. 220:241-245.

3. Peraldi, P., G.S. Hotamisligil, W.A. Buurman, M.F. White, and B.M Spiegelman. 1996. Tumor necrosis factor (TNF)- $\alpha$ inhibits insulin signaling through stimulation of the p55 TNF receptor and activation of sphingomyelinase. J. Biol. Chem. 271:13018-13022.

4. Caro, J.F., M.K. Sinha, J.W. Kolaczynski, P.L. Zhang, and R.V. Considine. 1996. Leptin: the tale of an obesity gene. Diabetes. 45:1455-1462.

5. Zhang, Y., R. Proenca, M. Maffei, M. Barone, L. Leopold, and J.M. Friedman. 1994. Positional cloning of the mouse obese gene and its human homologue. Nature. 372:425-432.

6. Pelleymounter, M.A., M.J. Cullen, M.B. Baker, R. Hecht, D. Winters, T. Boone, and F. Collins. 1995. Effects of the obese gene product on body weight regulation in $o b / o b$ mice. Science. 269:540-543.

7. Halaas, J.L., K.S. Gajiwala, M. Maffei, S.L. Cohen, B.T. Chait, D. 
Rabinowitz, R.L. Lallone, S.K. Burley, and J.M. Friedman. 1995. Weightreducing effects of the plasma protein encoded by the obese gene. Science. 269: $543-546$

8. Campfield, L.A., F.J. Smith, Y. Guisez, R. Devos, and P. Burn. 1995. Recombinant mouse OB protein: evidence for a peripheral signal linking adiposity and central neural networks. Science. 269:546-549.

9. Tartaglia, L.A., M. Dembski, X. Weng, N.H. Deng, J. Culpepper, R. Devos, G.J. Richards, L.A. Campfield, F.T. Clark, J. Deeds, et al. 1995. Identification and expression cloning of a leptin receptor, OB-R. Cell. 83:1263-1271.

10. Chen, H., O. Charlat, L.A. Tartaglia, E.A. Woolf, X. Weng, S.J. Ellis, N.D. Lakey, J. Culpepper, K.J. Moore, R.E. Breitbart, et al. 1996. Evidence that the diabetes gene encodes the leptin receptor: identification of a mutation in the leptin receptor gene in $d b / d b$ mice. Cell. 84:491-495.

11. Lee, G.H., R. Proenca, J.M. Montez, K.M. Carroll, J.G. Darvishzadeh, J.I. Lee, and J.M. Friedman. 1996. Abnormal splicing of the leptin receptor in diabetic mice. Nature. 379:632-635.

12. Ghilardi, N., S. Ziegler, A. Wiestner, R. Stoffel, M.H. Heim, and R.C. Skoda. 1996. Defective STAT signaling by the leptin receptor in diabetic mice. Proc. Natl. Acad. Sci. USA. 93:6231-6235.

13. Baumann, H., K.K. Morella, D.W. White, M. Dembski, P.S. Bailon, H.K. Kim, C.F. Lai, and L.A. Tartaglia. 1996. The full-length leptin receptor has signaling capabilities of interleukin 6-type cytokine receptors. Proc. Natl. Acad. Sci. USA. 93:8374-8378.

14. Rosenblum, C.I., M. Tota, D. Cully, T. Smith, R. Collum, S. Qureshi, J.F. Hess, M.S. Phillips, P.J. Hey, A. Vongs, et al. 1996. Functional STAT 1 and 3 signaling by the leptin receptor (OB-R). Reduced expression of the rat fatty leptin receptor in transfected cells. Endocrinology. 137:5178-5181.

15. Vaisse, C., J.L. Halaas, C.M. Horvath, J.E. Darnell, Jr., M. Stoffel, and J.M. Friedman. 1996. Leptin activation of Stat 3 in the hypothalamus of wildtype and $o b / o b$ mice but not $d b / d b$ mice. Nat. Genet. 14:95-97.

16. White, D.W., K.K. Kuropatwinski, R. Devos, H. Baumann, and L.A. Tartaglia. 1997. Leptin receptor (OB-R) signaling. Cytoplasmic domain mutational analysis and evidence for receptor homo-oligomerization. J. Biol. Chem. 272:4065-4071.

17. Emilsson, V., Y.L. Liu, M.A. Cawthorne, N.M. Morton, and M. Davenport. 1997. Expression of the functional leptin receptor mRNA in pancreatic islets and direct inhibitory action of leptin on insulin secretion. Diabetes. 46:313-316.

18. Fei, H., H.J. Okano, C. Li, G.H. Lee, C. Zhao, R. Darnell, and J.M. Friedman. 1997. Anatomic localization of alternatively spliced leptin receptors (Ob-R) in mouse brain and other tissues. Proc. Natl. Acad. Sci. USA. 94:70017005 .

19. Zachow, R.J., and D.A. Magoffin. 1997. Direct intraovarian effects of leptin: impairment of the synergistic action of insulin-like growth factor-I on follicle-stimulating hormone-dependent estradiol-17 $\beta$ production by rat ovarian granulosa cells. Endocrinology. 138:847-850.

20. Kieffer, T.J., R.S. Heller, and J.F. Habener. 1996. Leptin receptors expressed on pancreatic $\beta$-cells. Biochem. Biophys. Res. Commun. 224:522-527.

21. Bennett, B.D., G.P. Solar, J.Q. Yuan, J. Mathias, G.R. Thomas, and W. Matthews. 1996. A role for leptin and its cognate receptor in hematopoiesis. Curr. Biol. 6:1170-1180.

22. Yu, W.H., M. Kimura, A. Walczewska, S. Karanth, and S.M. McCann. 1997. Role of leptin in hypothalamic-pituitary function. Proc. Natl. Acad. Sci. USA. 94:1023-1028.

23. Gainsford, T., T.A. Willson, D. Metcalf, E. Handman, C. McFarlane, A. $\mathrm{Ng}$, N.A. Nicola, W.S. Alexander, and D.J. Hilton. 1996. Leptin can induce proliferation, differentiation, and functional activation of hemopoietic cells. Proc. Natl. Acad. Sci. USA. 93:14564-14568.

24. Bai, Y., S.Y. Zhang, K.S. Kim, J.K. Lee, and K.H. Kim. 1996. Obese gene expression alters the ability of 30A5 preadipocytes to respond to lipogenic hormones. J. Biol. Chem. 271:13939-13942.

25. Shimabukuro, M., K. Koyama, G. Chen, M.Y. Wang, F. Trieu, Y. Lee, C.B. Newgard, and R.H. Unger. 1997. Direct antidiabetic effect of leptin through triglyceride depletion of tissues. Proc. Natl. Acad. Sci. USA. 94:46374641.

26. Chen, G., K. Koyama, X. Yuan, Y. Lee, Y.T. Zhou, R. O'Doherty, C.B. Newgard, and R.H. Unger. 1996. Disappearance of body fat in normal rats induced by adenovirus-mediated leptin gene therapy. Proc. Natl. Acad. Sci. USA.
93:14795-14799.

27. Müller, G., J. Ertl, M. Gerl, and G. Preibisch. 1997. Leptin impairs metabolic actions of insulin in isolated rat adipocytes. J. Biol. Chem. 272:1058510593.

28. Zhou, Y.T., M. Shimabukuro, K. Koyama, Y. Lee, M.Y. Wang, F. Trieu, C.B. Newgard, and R.H. Unger. 1997. Induction by leptin of uncoupling protein-2 and enzymes of fatty acid oxidation. Proc. Natl. Acad. Sci. USA. 94:63866390 .

29. Ferre, P., A. Leturque, A.F. Burnol, L. Penicaud, and J. Girard. 1985. A method to quantify glucose utilization in vivo in skeletal muscle and white adipose tissue of the anaesthetized rat. Biochem. J. 228:103-110.

30. Terrettaz, J., F. Assimacopoulos-Jeannet, and B. Jeanrenaud. 1986. Severe hepatic and peripheral insulin resistance as evidenced by euglycemic clamps in genetically obese fa/fa rats. Endocrinology. 118:674-678.

31. James, D.E., K.M. Burleigh, and E.W. Kraegen. 1986. In vivo glucose metabolism in individual tissues of the rat. Interaction between epinephrine and insulin. J. Biol. Chem. 261:6366-6374.

32. Zapf, J., D. Feuerlein, M. Waldvogel, and E.R. Froesch. 1975. Increased sensitivity of diabetic rat adipose tissue towards the lipolytic action of epinephrine. Diabetologia. 11:509-516.

33. Rehnmark, S., J. Kopecky, A. Jacobsson, M. Nechad, D. Herron, B.D. Nelson, M.J. Obregon, J. Nedergaard, and B. Cannon. 1989. Brown adipose tissue differentiated in vitro can express the gene for the uncoupling protein thermogenin: effects of hypothyroidism and norepinephrine. Exp. Cell. Res. 182: $75-83$.

34. Shima, A., Y. Shinohara, K. Doi, and H. Terada. 1994. Normal differentiation of rat brown adipocytes in primary culture judged by their expressions of uncoupling protein and the physiological isoform of glucose transporter. Biochim. Biophys. Acta. 1223:1-8.

35. Ausubel, F.M., R. Brent, R.E. Kingston, D.D. Moore, J.G. Seidman, J.A. Smith, and K. Struhl. 1997. Current Protocols in Molecular Biology. J. Wiley \& Sons, Inc., New York.

36. Magnuson, M.A., H. Morioka, M.F. Tecce, and V.M. Nikodem. 1986. Coding nucleotide sequence of rat liver malic enzyme mRNA. J. Biol. Chem. 261:1183-1186.

37. Bernlohr, D.A., C.W. Angus, M.D. Lane, M.A. Bolanowski, and T.J. Kelly 1984. Expression of specific mRNAs during adipose differentiation: identification of an mRNA encoding a homologue of myelin P2 protein. Proc. Natl. Acad. Sci. USA. 81:5468-5472.

38. Schreiber, E., P. Matthias, M.M. Muller, and W. Schaffner. 1989. Rapid detection of octamer binding proteins with "mini-extracts," prepared from a small number of cells. Nucl. Acids Res. 17:6419.

39. Wagner, B.J., T.E. Hayes, C.J. Hoban, and B.H. Cochran. 1990. The SIF binding element confers sis/PDGF inducibility onto the c-fos promoter. $E M B O$ (Eur. Mol. Biol. Organ.) J. 9:4477-4484.

40. Castelein, H., T. Gulick, P.E. Declercq, G.P. Mannaerts, D.D. Moore, and M.I. Baes. 1994. The peroxisome proliferator activated receptor regulates malic enzyme gene expression. J. Biol. Chem. 269:26754-26758.

41. Hertz, R., V. Nikodem, A. Ben-Ishai, I. Berman, and J. Bar-Tana. 1996. Thyromimetic mode of action of peroxisome proliferators: activation of "malic" enzyme gene transcription. Biochem. J. 319:241-248.

42. Pearson, S.L., M.A. Cawthorne, J.C. Clapham, S.J. Dunmore, S.D. Holmes, G.B.T. Moore, S.A. Smith, and M. Tadayyon. 1996. The thiazolidinedione insulin sensitiser, BRL 49653, increases the expression of PPAR and $\mathrm{aP}_{2}$ in adipose tissue of high-fat-fed rats. Biochem. Biophys. Res. Commun. 229:752-757.

43. Chua, S.C., Jr., D.W. White, X.S. Wu-Peng, S.M. Liu, N. Okada, E.E. Kershaw, W.K. Chung, L. Power-Kehoe, M. Chua, L.A. Tartaglia, and R.L. Leibel. 1996. Phenotype of fatty due to Gln269Pro mutation in the leptin receptor (Lepr). Diabetes. 45:1141-1143.

44. Phillips, M.S., Q.Y. Liu, H.A. Hammond, V. Dugan, P.J. Hey, C.T. Caskey, and J.F. Hess. 1996. Leptin receptor missense mutation in the fatty Zucker rat. Nat. Genet. 13:18-19.

45. Chua, S.C., Jr., W.K. Chung, X.S. Wu-Peng, Y.Y. Zhang, S.M. Liu, L. Tartaglia, and R.L. Leibel. 1996. Phenotypes of mouse diabetes and rat fatty due to mutations in the OB (leptin) receptor. Science. 271:994-996. 